\title{
Building envelop energy efficient retrofitting options for domestic buildings in the UK
}

\author{
A. Brannigan \& C. A. Booth \\ Construction and Property Research Centre, \\ University of the West of England (UWE), Bristol, UK
}

\begin{abstract}
Retrofitting options to improve the thermal efficiency of external walls of domestic buildings are presented for three types of properties built in the UK. Case study one is a semi-detached, two-storey building, built ca. 60 years ago, with a brick outer skin, a hollow cavity and a block work inner skin; case study two is a mid-terraced, two-storey building built $\mathrm{ca}$. 120 years ago, with a solid stone wall and render; and case study three is a semi-detached, two-storey building, built ca. 60 years ago, with a reinforced pre-cast concrete outer skin, a cavity and a block work inner skin. The most appropriate retrofitting options considered were: (i) installing cavity insulation; (ii) attaching internal wall insulation; and (iii) mounting external wall insulation, respectively. In each case study the retrofitting options demonstrate notable improvements can be made in the thermal performance of the buildings. Moreover, all retrofit approaches provide sizeable energy cost savings per annum, with case study three providing the largest savings and case study one proffering the shortest payback period. Cavity wall insulation emerged as most beneficial retrofit option, in regards to capital cost, quickest payback period and minimal disruption in the installation process. However, homeowner motivation to instigate retrofit options is acknowledged as a significant barrier and, when married with the associated disruption and inconvenience of implementing home improvements, it is viewed as a massive hurdle requiring research attention.
\end{abstract}

Keywords: building thermal performance, housing, insulation, energy saving, payback period. 


\section{Introduction}

Domestic heating costs for UK households have risen by a staggering 53\% from 2006 to 2011 [1], which is prompting homeowner interest in energy efficient property alteration options. Improvements will help homeowners to reduce utility bills and assist governments to meet carbon emission reduction targets. Changes to Part L of the Building Regulations will increase the energy efficiency of new buildings to enable Zero Carbon Homes by 2016 [2] but initiatives for existing properties (e.g. The Green Deal) have been slower to instigate.

The capital outlay cost to bring about energy efficient improvements is a major factorial barrier for many homeowners [3] and, therefore, the payback period is a fundamental influence on the decision-making process for most people. Buildings constructed with high thermal resistance materials are beneficial to heat loss reduction but are most likely to have greater capital costs [4]. Although walls may not have the worst U-Values of the various elements of the building envelop, due to their large areas, they are responsible for losing the most heat from domestic buildings [5].

This study appraises the retrofitting options of three types of domestic properties, typical of many towns and cities in the UK, to improve the thermal efficiency of external walls of the buildings with the intention of lessening carbon usage, reducing utility costs and providing insights of the probable payback periods.

\section{Background}

Climate change is causing an array of challenges for the built environment and is the focus of national and international attention [6]. The UK was the first nation to have a legally binding framework [7] to cut carbon emissions, with a 2050 target of an $80 \%$ reduction from the 1990 baseline [8]. This is a courageous ambition and requires major changes to the design and construction of new buildings, alterations to existing buildings and an overall shift in energy usage and human-behaviour.

In light of the current economic downturn, construction of new domestic properties has fallen by $38 \%$ from 175,560 in 2007 , down to just 109,020 in 2011 [9]. It is anticipated that $80 \%$ of the existing housing stock will still be occupied by 2050 [10] and indicates that making only new homes energy efficient (e.g. Zero Carbon Homes) will not be suffice to meet carbon emission reduction targets.

Existing housing stock in the UK is one of the oldest in Europe, with 21\% constructed prior to 1919 and only 12\% after 1990 [11]. With stringent modern building regulations not covering a large percentage of these properties when originally built, retrofitting alterations to the thermal performance of these buildings represents great opportunity to improve energy efficiency and reduce carbon emissions.

The main elements of the building fabric that lose heat are: the walls (33\%), roof (26\%), windows (18\%), doors and floors (11\% combined) and with 
draughts throughout the property accounting for the remaining 12\% [12]. Even though walls do not possess the worst U-Value of the various elements, their size (in comparison to window or door sizes, for instance) signifies they are the greatest loser of heat within the fabric of the building [2012]. The percentage of total heat loss increases to $45 \%$ for dwellings containing solid external walls [13]. Hopper et al. [14] proffers the greatest opportunity for reducing energy consumption in domestic buildings is through improving the thermal performance of solid external walls.

Sadly, there is not a 'one-size-fits-all' approach to improving the energy efficiency of external walls across the range of housing stock. DCLG [11] state that a masonry cavity wall consisting of two skins of brick or blockwork, along with a cavity air space, is the most common type of wall construction within the existing housing stock (accounting for 65\% of existing UK houses). Cavity walls became the popular construction option among house builders from 1920 onwards. Before this date, the use of solid masonry walls was the preferred method for house builders (accounting for $28 \%$ of existing UK houses).

Part L of the current Building Regulations [15] for new domestic dwellings indicates that external walls of a property cannot exceed a U-Value of 0.30 $\mathrm{W} / \mathrm{m}^{2} \mathrm{~K}$. Walls of existing buildings have considerably higher values than this due to these regulations not being in place at the time of construction. For instance, until 1965 there was no requirement to incorporate insulation into the design of new domestic properties [16].

\section{Methods}

Three types of domestic buildings were chosen, which typify housing across the UK: (i) case study one is a semi-detached, two-storey building, built $c a$. 60 years ago, with a brick outer skin, a cavity and a block work inner skin (Figure 1(a)); (ii) case study two is a mid-terraced, two-storey building built $c a$. 120 years ago, with a solid stone wall and render (Figure 1(b)); and (iii) case study three is a semi-detached, two-storey building, built ca. 60 years ago, with a reinforced precast concrete outer skin, a cavity and a block work inner skin (Figure 1(c)).

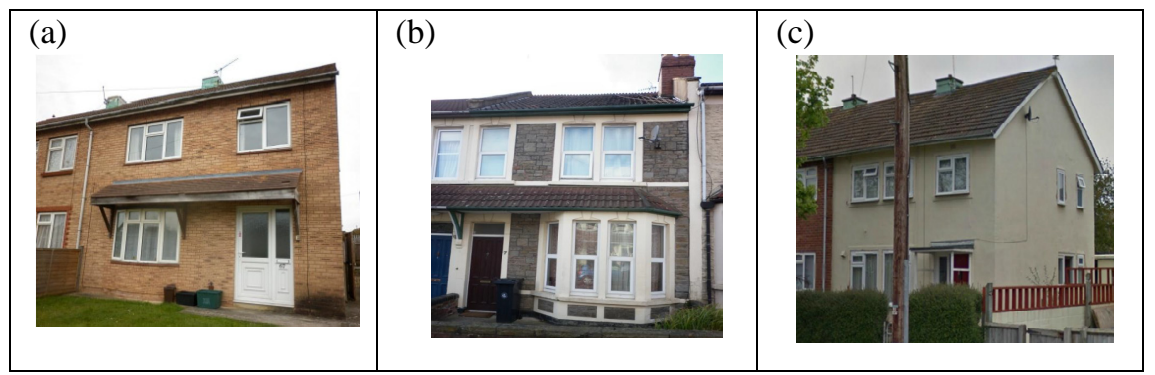

Figure 1: Photographs of the three case study buildings used in this investigation. 
A building survey was conducted for each property to enable the thermal performance of the buildings to be determined. Table 1 illustrates the U-values, fabric heat loss and potential costings for the three case studies (without retrofit options applied). These calculations are based on several assumptions about occupant behaviour, derived from Shipworth et al. [17], which reveal most home heating systems are active for about 9.5 hours per day with a preferred room temperature of $19^{\circ} \mathrm{C}$. Heating costs are based on the standard tariff rate obtained from British Gas (4.65p/kWh - correct as of January 2013).

Table 1: Indicative U-values, fabric heat loss and potential costings for the three case studies (without retrofit options applied).

\begin{tabular}{|l|c|c|c|}
\hline & Case Study 1 & Case Study 2 & Case Study 3 \\
\hline Wall U-Value & $1.38 \mathrm{~W} / \mathrm{m}^{2} \mathrm{~K}$ & $2.30 \mathrm{~W} / \mathrm{m}^{2} \mathrm{~K}$ & $1.45 \mathrm{~W} / \mathrm{m}^{2} \mathrm{~K}$ \\
\hline Fabric heat loss & $13,401.16 \mathrm{~W}$ & $12,916.80 \mathrm{~W}$ & $16,625.70 \mathrm{~W}$ \\
\hline Heating Units & $46,468.52 \mathrm{kWh}$ & $44,789.00 \mathrm{kWh}$ & $57,649.61 \mathrm{kWh}$ \\
\hline $\begin{array}{l}\text { Cost of heating lost } \\
\text { through walls per } \\
\text { annum }\end{array}$ & $£ 2,160.79$ & $£ 2,082.69$ & $£ 2,680.71$ \\
\hline $\begin{array}{l}\text { Size of external } \\
\text { wall area }\end{array}$ & $83 \mathrm{~m}^{2}$ & $48 \mathrm{~m}^{2}$ & $98 \mathrm{~m}^{2}$ \\
\hline $\begin{array}{l}\text { Cost of heating lost } \\
\text { through 1m² of wall } \\
\text { per annum }\end{array}$ & $£ 26.03$ & $£ 43.39$ & $£ 27.35$ \\
\hline
\end{tabular}

\section{Results}

Proposed retrofitting options for case studies are presented, whereby case study one benefits from installing cavity insulation (Figure 2); case study two benefits from attaching internal wall insulation (Figure 3); and case study three benefits from mounting external wall insulation (Figure 42).

The original wall for case study one (Figure 2(a)) is constructed with an external leaf facing brick, $50 \mathrm{~mm}$ open cavity and $100 \mathrm{~mm}$ internal brickwork that has been internally plastered and painted. The preferred retrofit option for this property is to install cavity wall insulation due to the significant capital cost saving, minimal disruption during the installation process and no significant changes to the external and internal aesthetics of the property. Figure 2(b) shows the same wall structure with cavity fully filled with polystyrene bead insulation. Other products that could be utilised for the cavity fill, including mineral wool and foamed insulants [18]. The process is carried out by drilling holes into the external wall and injecting the insulation into the cavity, carried out by a trained operative. The Energy Saving Trust estimates the cost of this for a threebedroom semi-detached to be in the region of $£ 100-£ 350$ including all necessary labour and materials [18]. 


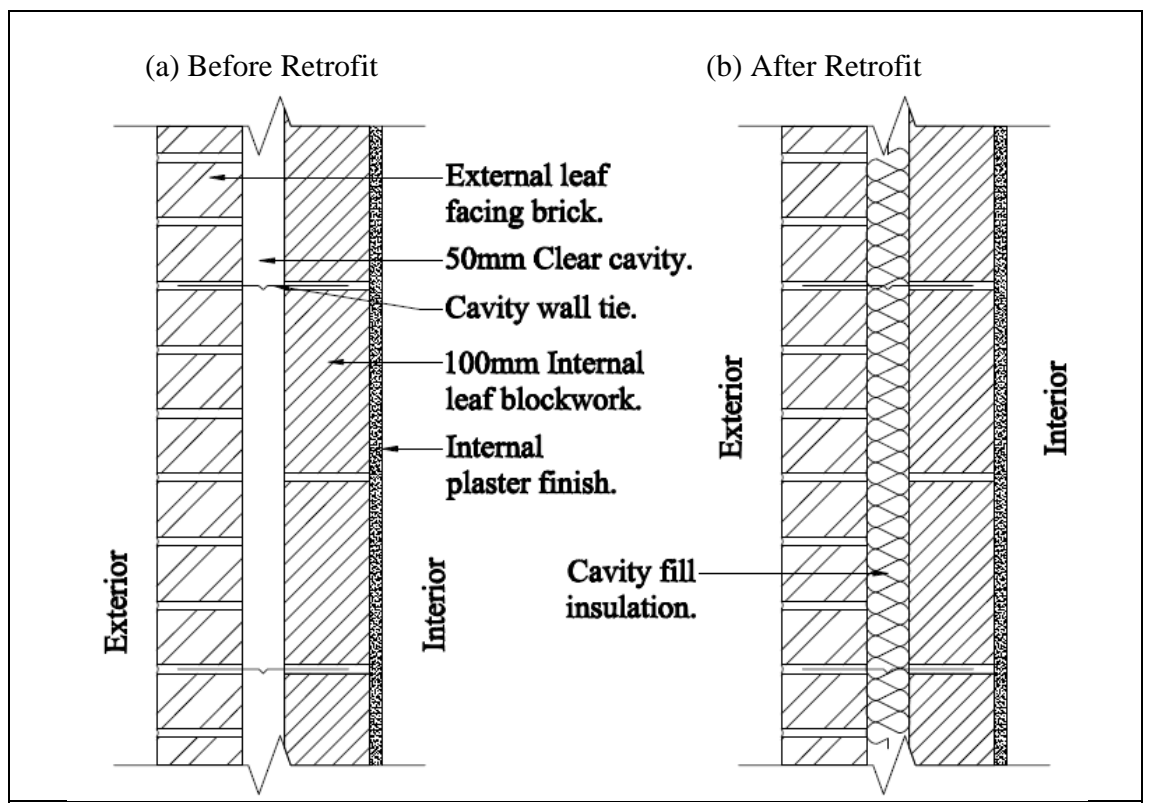

Figure 2: $\quad$ Illustrated cross section through the external wall of building used in case study one (a) before retrofitting and (b) after retrofitting.

The original wall for case study two (Figure 3(a)) is constructed of a $225 \mathrm{~mm}$ solid stone wall, internally plastered and painted. The preferred retrofit option for this property is to install internal wall insulation. This is due to the external aesthetics of the building remaining unchanged (planning permission may also be required for this type of property) and that cavity wall insulation is not an option within a solid existing wall. Figure 3(b) shows the same solid wall; however, it has now been installed with an internal, 95mm thick, insulating layer and a new finish coat of plaster. The insulation is the ThermoShell Internal Wall Insulating System from Knauf Insulation. It consists of timber battens fixed to the existing wall at $600 \mathrm{~mm}$ centres, infilled with mineral wool. This is just one of many internal insulation options available for home owners in the UK market. It is noteworthy, that any fixtures or fittings within the property (i.e. skirting boards, fitting kitchens and bathrooms) will need to be removed and re-fitted following the installation of the insulation. The Energy Saving Trust estimates the cost of this for a three-bedroom semi-detached to be in the region of $£ 5,500$ $£ 8,500$ including all necessary labour and materials [13].

The original wall for case study three (Figure 4(a)) is constructed of a precast concrete external leaf, 50mm open cavity and a $100 \mathrm{~mm}$ thick internal blockwork leaf that has received a plaster finish. The preferred retrofit option for this property is to install external wall insulation. The stance taken here is that the new external finish will actually improve the aesthetics of the building and not have a detrimental effect, as is the scenario in case study two. With the tenants of the building requesting minimal internal disruption (i.e. removing and refitting of 


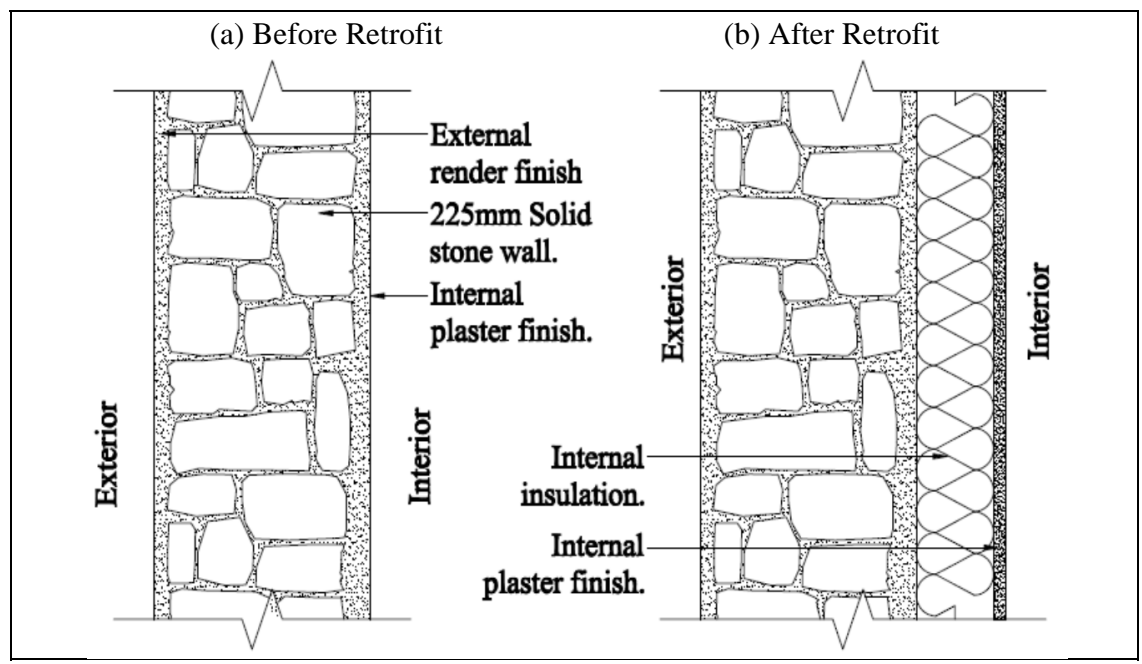

Figure 3: $\quad$ Illustrated cross section through the external wall of building used in case study two (a) before retrofitting and (b) after retrofitting.

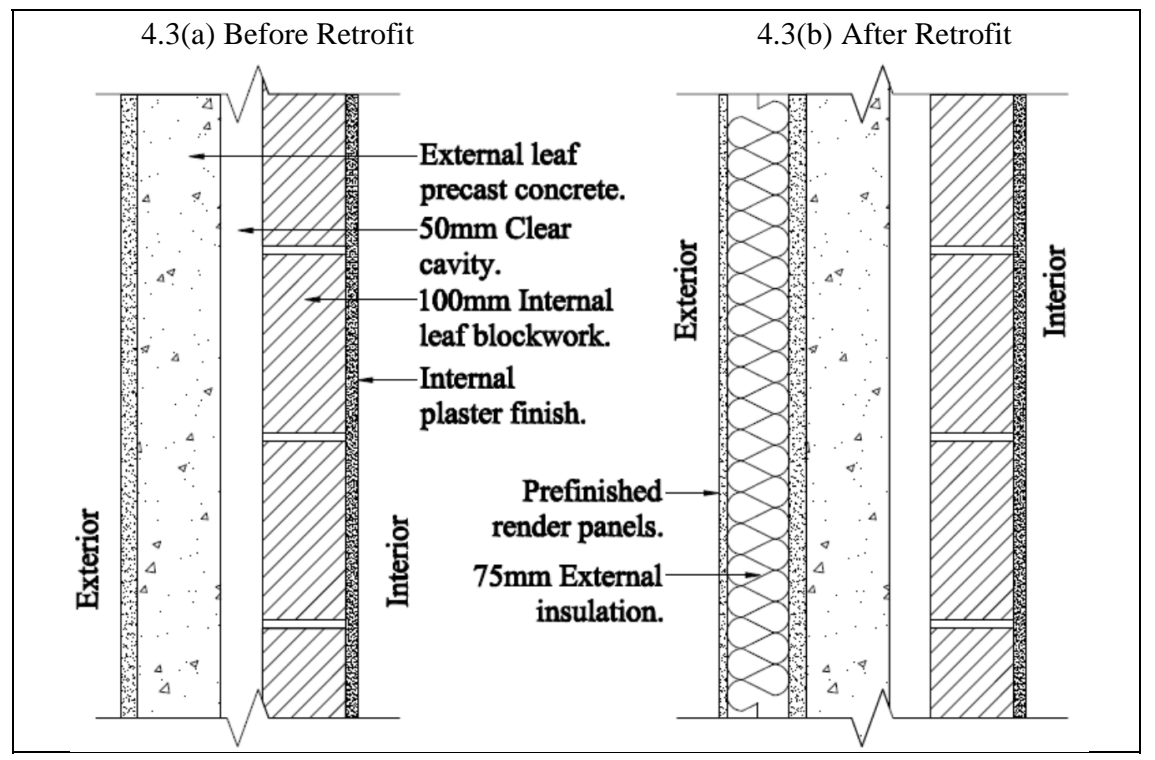

Figure 4: $\quad$ Illustrated cross section through the external wall of building used in case study three (a) before retrofitting and (b) after retrofitting.

the kitchen and bathroom), external insulation would be the chosen option. Figure 4(b) shows the same wall; however, it has now been retrofitted with an external $75 \mathrm{~mm}$ thick mineral wool insulating layer. The external finish is a prefinished render panel from Steni UK and available for installation by Bagnalls 
contractors. This is just one of many external insulation options available for home owners in the UK market. The Energy Saving Trust estimates the cost of this for a three-bedroom semi-detached to be in the region of $£ 9,400-£ 13,000$ including all necessary labour and materials [13].

Based on the same assumptions applied earlier, the gains in making these alterations is realised by indicative U-values, fabric heat loss and potential costings after retrofit options have been applied (Table 2). In each case study the retrofitting options demonstrate notable improvements in the thermal performance of the buildings (e.g. from $2.30 \mathrm{~W} / \mathrm{m}^{2} \mathrm{~K}$ to $0.35 \mathrm{~W} / \mathrm{m}^{2} \mathrm{~K}$ for case study two).

Table 2: $\quad$ Indicative U-values, fabric heat loss and potential costings for the three case studies (after retrofit options applied).

\begin{tabular}{|l|c|c|c|}
\hline & Case Study 1 & Case Study 2 & Case Study 3 \\
\hline Wall U-Value & $0.49 \mathrm{~W} / \mathrm{m}^{2} \mathrm{~K}$ & $0.35 \mathrm{~W} / \mathrm{m}^{2} \mathrm{~K}$ & $0.35 \mathrm{~W} / \mathrm{m}^{2} \mathrm{~K}$ \\
\hline Fabric heat loss & $4,758.39 \mathrm{~W}$ & $1,965.60 \mathrm{~W}$ & $4,013.10 \mathrm{~W}$ \\
\hline Heating Units & $16,499.72 \mathrm{kWh}$ & $6,815.72 \mathrm{kWh}$ & $13,915.42 \mathrm{kWh}$ \\
\hline $\begin{array}{l}\text { Cost of heating lost } \\
\text { through walls per } \\
\text { annum }\end{array}$ & $£ 767.24$ & $£ 316.93$ & $£ 647.07$ \\
\hline
\end{tabular}

Previous work [19] suggests most homeowners are unlikely to instigate alterations unless there is an immediate cost benefit and they are likely to see a rapid return on their investment. Therefore, it is important to know the payback periods. Using the highest retrofit prices for each case study (outlined earlier), based on the Energy Saving Trust, Table 3 illustrates all retrofit approaches provide sizeable cost savings per annum, with case study three providing the largest savings for the size of building, case study one proffering the shortest payback period (because the retrofit approach involves the least capital outlay)

Table 3: Indicative cost savings, expected payback periods and carbon reductions from implementing the retrofitting options for the three case studies.

\begin{tabular}{|l|c|c|c|}
\hline & Case Study 1 & Case Study 2 & Case Study 3 \\
\hline $\begin{array}{l}\text { Capital cost (EST, } \\
\text { 2012a,b) }\end{array}$ & $£ 350$ & $£ 8,500$ & $£ 13,000$ \\
\hline $\begin{array}{l}\text { Potential savings } \\
\text { per annum }\end{array}$ & $£ 1,394$ & $£ 1,766$ & $£ 2,033$ \\
\hline $\begin{array}{l}\text { Saving/annum/m² of } \\
\text { wall area }\end{array}$ & $£ 16.79$ & $£ 36.79$ & $£ 20.75$ \\
\hline $\begin{array}{l}\text { Expected payback } \\
\text { period }\end{array}$ & $\sim 90$ days & $\sim 5$ years & $\sim 6.5$ years \\
\hline $\begin{array}{l}\text { CO }{ }_{2} \text { emissions } \\
\text { reduction per } \\
\text { annum }\end{array}$ & $\sim 550 \mathrm{~kg}$ & 1.8 tonnes & 1.9 tonnes \\
\hline
\end{tabular}


and case study two offers the greatest saving per $\mathrm{m}^{2}$ of wall. The payback period is then taken from the savings per annum of the heating cost against the initial cost of installing the retrofit option.

\section{Discussion}

Despite this work only focussing on three properties, the findings support existing literature $[18,20]$. The cheapest and easiest to install would be the cavity wall insulation. This is due to it not requiring the removal and reinstalling of any fixtures or fittings both internally or externally. The installation process does not disrupt the occupants and leaves minor alterations to the external aesthetics of the building.

The great increase in capital cost pushes the payback periods from three months up to five and six and a half years for internal and external wall insulation, respectively. The importance of the capital cost is enhanced when we see cavity wall insulation produces the lowest heat loss saving per annum per $\mathrm{m}^{2}$ of wall area.

Internal wall insulation offers the greatest reduction in heating costs from the three case studies, with a saving of $£ 36.79$ per annum per $\mathrm{m}^{2}$ of wall. The main reason for this is the thickness of the insulation that has been required to comply with the recently tightened Building Regulations [21]. The main barriers to proceeding with this approach is the homeowner would lose $95 \mathrm{~mm}$ from the internal face of all the external walls (especially in the smaller rooms) and is it even technically feasible around WCs, sinks, radiators, fitted kitchens and bathrooms.

The choice of retrofit option for any home owner is governed by the construction of the existing external wall. A wall without a cavity air gap cannot receive cavity wall insulation; therefore, only two options remain. As well as the greatly increased capital cost already discussed, both options present additional problems to homeowners (and occupiers of the building if these are not the same people). The disruption caused when removing and reinstalling fixtures and fittings (including bathrooms and kitchens) when adding a layer of internal wall insulation, as well as the reduced room sizes, may be enough to prevent the works from proceeding. External wall insulation involves a radical change to the external aesthetics of a dwelling, which can be seen as a positive or a negative consequence. Even though the planning constraints associated with external wall insulation have been relaxed to help promote the uptake of financial loan incentives, it is advised that any homeowner wanting to install this energy saving measure consults their local authority to prevent any unnecessary problems in the near future.

It is easy to get overwhelmed with the importance of the external walls to the domestic buildings within the three case studies and across the existing housing stock. It is essential for any homeowner to understand that even though walls are a major element of heat loss, there are other sections of the building where energy savings can be made. The roof and windows in particular, account for up to $26 \%$ and $18 \%$ of the total building heat loss, respectively [12]. Simple 
retrofitting measures to these elements, such as loft insulation and draught proofing strips can also increase the energy efficiency of domestic properties.

Even with the evidence collated in this work, proving that retrofit options are both technically and economically viable for domestic properties within the UK, it is still unclear whether owner-occupiers possess the motivation to undertake energy efficiency refurbishments. Organ et al. [22] categorises the reasons why a homeowner would proceed with an energy efficiency refurbishment to their property in to three key areas. These include economic factors, such as potential savings to heating bills and value added to the property. Social factors may also provide motivation to homeowners, such as increased comfort levels and a sense of responsibility. The final category is the environmental factor, including wanting to reduce their carbon footprint and offering resilience to climate change. All of these may be causes why a homeowner would seek any of the retrofit options.

Since the capital cost of any retrofit option has a significant bearing on the overall payback period the savings made to the heating costs would be of minor importance to a homeowner if a large capital cost forces the payback period in excess of their expected occupation of a building. In most circumstances (unless due for demolish) any retrofit option would make economic sense across the overall life of the building. Problems occur when homeowners expect to sell the property and move. Therefore, they do not gain the benefits of their investment.

With the capital cost being a major barrier in the uptake of energy efficient retrofit measures, the UK Government initiatives are looking to mitigate this challenge. Projects such as the Warm Front Scheme (www.gov.uk/warm-frontscheme) and the Carbon Emissions Reduction Target (www.energysaving trust.org.uk) have now been encompassed into The Green Deal (www.greendealinitiative.co.uk) and the Energy Company Obligation (www.ofgem.gov.uk). The Green Deal was fully established in January 2013 and takes away this capital cost by offering a grant to homeowners to improve the energy efficiency of their property. The savings made to the heating costs will be used to repay this debt. One main difference to this scheme as opposed to the previous initiatives is that the investment is to the property and not the homeowner. Therefore, if there is a change in ownership, the debt and savings stay with the new landlord.

The dilemma of personal motivation becomes more ambiguous when properties are rented privately to tenants who pay the utility costs. Highmore [23] report many landlords have been reluctant to invest in energy efficiency measures because it is the tenant(s) who obtain the benefit of lower energy costs. The landlord has no financial gain from any reduction in energy costs caused by investing in an energy efficient retrofit to the property. The only option the owner has would be to increase the rental payments, which in an ever increasing rental market may be difficult to do and encourage new tenants to take on the rental lease at the same time.

It is understandable that building fabric, internal heating systems and behaviour of those occupying buildings are intrinsically interlinked and influence the energy usage and efficiency of a building [24]. A well designed energy 
efficient building that is poorly run will perform inadequately. It is of modest use to possess an energy efficient building if the occupiers leave windows open throughout the winter resulting in excessive heat loss. Therefore, any technological changes to existing housing stock (including retrofit options) needs to be accompanied by a cultural change, with occupants of a building understanding their actions have a direct impact on energy usage and costs.

\section{Conclusions}

It is clear to see that there is not a 'one-size-fits-all' solution to improving the energy efficiency of the building envelop to existing housing stock. The variety in construction methods illustrates a requirement of applying one of the retrofit options to match the property in question, rather than trying to produce one resolution and applying it to every home.

The cavity wall insulation retrofit option emerges to be considerably cheaper in the capital cost, cause minimal disruption in the installation process, leave minimal external aesthetic 'damage' and also produce a very short payback period for investors. This has not gone unnoticed by the UK Government, who in the past has offered monetary grants for homeowners to take advantage of this retrofit technique under the Warm Front Scheme [25]. This has now been encompassed into The Green Deal.

With regards to internal and external wall insulation, to increase the uptake of these is much more difficult, mainly due to the large capital cost and long payback periods. The disruption and inconvenience caused to homeowners when attaching and mounting insulation is problematic and is something the government can do nothing about. Together with the psychological aspects of human motivation, this will continue to be one of the major barriers preventing uptake of retrofitting options for the building envelop of domestic properties in the UK.

\section{References}

[1] Department of Energy and Climate Change (2012) Quarterly Energy Prices Table. London, UK: DECC. http://www. decc.gov.uk/en/content/cms /statistics/publications/prices/prices.asp.

[2] Department for Communities and Local Government (2007) Building a Greener Future: Policy Statement. West Yorkshire, UK: DCLG Publication.

[3] McLeod, P. and Fay, R. (2011) Costs of improving the thermal performance of houses in a cool-temperate climate. Architectural Science Review. 53 (3), pp. 307-314.

[4] Judkoff, R. (2008) Increasing Building Energy Efficiency Through Advances in Materials. MRS Bulletin. 33 (4), pp. 449-454.

[5] Burberry, P. (1992) Mitchell's Building Series Environment \& Services. 7th ed.: Longman Scientific \& Technical. 
[6] Booth, C.A., Hammond, F.N., Lamond, J.E. and Proverbs, D.G. (2012) Solutions to Climate Change Challenges in the Built Environment. WileyBlackwell, Oxford.

[7] Royal Ascent (2009) Climate Change Act 2008 c. 27. London, UK: HM Stationary Office (415435).

[8] Department of Energy and Climate Change (2011) UK Renewable Energy Roadmap. https://www.gov.uk/government/uploads/system/uploads/ attachment_data/file/48128/2167-uk-renewable-energy-roadmap.pdf.

[9] The Chartered Institute of Housing (2012) CIH Housing Facts and Figures. http://www.cih.org/resources/PDF/Marketing\%20PDFs/Key\%20statistics\% 20for\%20web\%20-\%20housing\%20supply.pdf.

[10] Hunt, M. (2008) Bringing the housing stock up to scratch. The Future is Retro-Fit. 1, p. 3.

[11] Department for Communities and Local Government (2010) English Housing Survey: Housing Stock Report 2008. London, UK: DCLG.

[12] Ecopower Heating (2012) Electric Heating Bills Reduced - For Free! http://www.ecopowerheating.co.uk/2012/01/electric-heating-bills-reducedfor-free.

[13] Energy Saving Trust (2012b). Solid Wall Insulation. Available from: http://www.energysaving trust.org.uk/Insulation/Solid-wall-insulation.

[14] Hopper, J., Littlewood, J.R., Taylor, T., Counsell, J.A.M., Thomas, A.M., Karani, G., Geens, A. and Evans, N.I. (2012) Assessing retrofitted external wall insulation using infrared thermography. Structural Survey. 30 (3), pp. 245-266.

[15] HM Government (2010a) The Building Regulations 2010: Conservation of fuel and power in new dwellings. Approved Document L1A. London, UK: NBS.

[16] Castleton, H.F., Stovin, V., Beck, S.B.M. and Davison, J.B. (2010) Green roofs; building energy savings and the potential for retrofit. Energy and Buildings. 42 (10), pp. 1582-1591.

[17] Shipworth, M., Firth, S.K., Gentry, M.I., Wright, A.J., Shipworth, D.T. and Lomas, K.J. (2010) Central heating thermostat settings and timing: building demographics. Building Research \& Information. 38 (1), pp. 50-69.

[18] Energy Saving Trust (2012a). Cavity Wall Insulation. http://www.energysavingtrut.org.uk/Insulation/Cavity-wall-insulation.

[19] Banfi, S., Farsi, M., Filippini, M. and Jakob, M. (2008) Willingness to pay for energy-saving measures in residential buildings. Energy Economics. 30 (2), pp. 503-516.

[20] YouGen (2013) Insulation. http://www.yougen.co.uk/energy-saving/ Insulation.

[21] HM Government (2010b) The Building Regulations 2010: Conservation of fuel and power in existing dwellings. Approved Document L1B. London, UK: NBS.

[22] Organ, S., Proverbs, D. and Squires, G. (2013) Motivations for energy efficiency refurbishment in owner-occupied housing. Structural Survey. 31, pp. 101-120. 
486 The Sustainable City VIII, Vol. 1

[23] Highmore, S. (2013) Putting Your Energy Into Efficiency. Estates Gazette. 1 (1306), pp. 96-98.

[24] Morrell (2010) Low Carbon Construction: Innovation \& Growth Team. London, UK: HM Government.

[25] HM Government (2012) Warm Front Scheme: Overview. https://www.gov.uk /warm-front-scheme/overview. 